\title{
Escova dental e dedeira na remoção da placa bacteriana dental em cães
}

\author{
The dental brush and thumb-stall in the removal of the dental plaque in dogs
}

\author{
Tânia Berbert Ferreira Lima ${ }^{1}$ Duvaldo Eurides ${ }^{2}$ Renata Junqueira Rezende ${ }^{3}$ \\ Vanessa Martins Fayad Milken ${ }^{3}$ Luiz Antonio Franco da Silva ${ }^{4}$ Maria Clorinda Soares Fioravanti ${ }^{4}$
}

\section{RESUMO}

A placa bacteriana é fator primário na formação de gengivite, cálculo dentário, halitose e doença periodontal. Objetivou-se avaliar a quantidade de placa bacteriana dental removida pela escova dental e dedeira. Foram utilizados 60 cães machos e fêmeas de diferentes raças, idade e peso, divididos em dois grupos. $O$ indice Logan \& Boyce foi utilizados para quantificar a placa bacteriana antes e após a escovação. Observou-se diferença estatística $(p<0,05)$ na remoção da placa bacteriana antes e após escovação. Não houve diferença estatística $(p>0,05)$ entre a utilização da escova dental e a dedeira.

Palavras-chave: cães, placa bacteriana, doença periodontal, dente. ABSTRACT

The dental plaque is the primary factor for gingivitis formation, dental calculus, oral malodor and periodontal disease. To evaluate the amount of dental plaque removed by the dental brush and thumb-stall, 60 male and female dogs of different races, age and weight were divided in two groups and studies. The index of Logan \& Boyce was used to quantify the dental plaque before and after the toothbrush. Statistical difference was observed $(p<0.05)$ in the removal of the bacterial plate before and after toothbrush. There was not statistical difference ( $p>0.05)$ between the use of the dental brush and the thumb-stall.

Key words: $\operatorname{dog} s$, dental plaque, disease periodontal, toothbrush.

\section{INTRODUÇÃO}

A odontologia veterinária no Brasil vem se desenvolvendo nos últimos anos, porém, existem poucos os trabalhos ligados à realidade brasileira (EURIDES et al., 1996). Cerca de 85\% dos cães acima de quatro anos de idade que freqüentam as clínicas veterinárias apresentam doença periodontal (COLMERY \& FROST, 1986; LYON, 1991), o que pode constituir grave problema de saúde bucal, podendo interferir na qualidade de vida dos animais (DEBOWES et al., 1996).

A doença periodontal crônica em cães pode ocasionar perturbações sistêmicas, as quais têm sido atribuída à bacteremia e à concentração de toxinas bacterianas na cavidade oral (EISNER, 1989; DEBOWES et al., 1996). Dentre as conseqüências pode-se observar bronquite crônica, fibrose pulmonar, endocardiose, endocardite, nefrite intersticial, glomerulonefrite e hepatite (DEBOWES et al., 1996; DUPONT, 1997).

O fator primordial para que ocorra doença periodontal tanto em humanos quanto em cães, é a placa bacteriana (SILVA et al., 1997), que é formada de 3 a 24 horas após a profilaxia da superfície dental (DUPONT, 1998; HARVEY, 1998). A placa bacteriana é um biofilme organizado aderido à superfície dos dentes, composta por restos alimentares, saliva, polissacarídeos extracelulares, restos celulares, leucócitos, macrófagos, lipídios, carboidratos e bactérias, principalmente aeróbias. Este material antigênico em contato constante com a gengiva marginal (DUPONT, 1998) provoca uma resposta inflamatória denominada gengivite que, em indivíduos

'Odontólogo, Mestrando em Ciências Veterinárias, Clínica e Cirurgia, (COMEV), Faculdade de Medicina Veterinária (FAMEV), Universidade Federal de Uberlândia (UFU). E-mail:paulalima@ufu.br

${ }^{2}$ Médico Veterinário, Professor Titular, Doutor, FAMEV, UFU. Av. Pará, 1720, Campus Umuarama, 38400-902, Uberlândia, MG.

E-mail:duvaldo@ufu.br Endereço para correspondência.

${ }^{3}$ Medico Veterinário, Mestrando, COMEV, FAMEV, UFU.

${ }^{4}$ Médico Veterinário, Professor Adjunto, Doutor, Escola de Veterinária, Universidade Federal de Goiás. 
susceptíveis, pode progredir para periodontite (DUPONT, 1997). A incidência de gengivite está relacionada à falta de higiene oral e desaparece quando a placa é removida (SILVA et al., 1997; HARVEY, 1998).

O cálculo dental, formado pela mineralização da placa bacteriana, embora não seja um irritante gengival ativo, como a placa, pode ser um irritante gengival passivo local e também agir como superfície de retenção de placa (DUPONT, 1997). Outra consequiência da placa bacteriana pode ser a halitose (PINTO \& ISSÁO, 1988; RICHTER, 1996 e CULHAM \& RAWLINGS, 1998).

A higiene oral, além da profilaxia profissional executada em intervalos regulares, é necessária para prevenir a gengivite (DUPONT, 1997). $\mathrm{O}$ tratamento periodontal que não segue um controle adequado da placa bacteriana, resulta em insucesso, uma vez que pode ocorrer recidiva quando permanece instalada nos dentes (GROVE, 1998). A prevenção surge como um aspecto essencial para diminuir a doença periodontal e manter os dentes dos animais durante toda a sua vida (LYON, 1991). A prevenção requer remoção da placa sub e supra-gengival através de escovação, produtos mastigáveis, antibióticoterapia e agentes antibactericidas (JENSEN et al., 1995). A escova dental destrói o biofilme através do atrito (D'APINO, 1992, ANDRADE JR. et al., 1998 e DUPONT, 1998), porém, o uso inadequado pode aumentar a prevalência de doença periodontal em humanos (JONGENELIS \& WIEDEMANN, 1997). Para a manutenção da gengiva saudável em cães, a escovação pode ser realizada três vezes por semana (TROMP et al., 1986; DUPONT, 1998). Entretanto, na presença de gengivite deverá ser efetuada diariamente (CORBA et al., 1986; TROMPet al., 1986; DUPONT, 1998).

De acordo com MILLER \& HARVEY (1994) menos de $10 \%$ dos proprietários de cães concordam com as recomendações para escovar os dentes de seus animais. No entanto, se habituassem a realizar escovação em seus cães, poderia ocorrer redução de $90 \%$ na predisposição à periodontite, pelo controle da placa bacteriana (DUPONT, 1998).

O objetivo deste estudo foi comparar a eficiência da remoção da placa bacteriana dental com a escova dental e a dedeira em cães.

\section{MATERIAL E MÉTODOS}

Foram utilizados 60 cães, 23 machos e 37 fêmeas de diferentes raças, com idades variando de 7 meses a 12 anos, com peso corporal entre 1 a $24 \mathrm{~kg}$, todos portadores de placa bacteriana, separados em dois grupos de 30 animais. No Grupo I, utilizou-se a escova dental infantila extra macia com $3 \times 6$ fileiras de cerdas e, no Grupo II, a dedeira ${ }^{\mathrm{b}}$ de borracha monobloco com $22 \times 9$ fileiras de cerdas, as quais foram reutilizadas depois de enxaguadas em solução de hipoclorito de sódio ${ }^{c}$.

As placas bacterianas foram visualizadas na superfície vestibular dos dentes após aplicação tópica de solução Violeta de Genciana a $0,1 \%$, embebida em algodão hidrófilo (EURIDES et al., 1996).

LOGAN \& BOYCE (1994) propõem um índice de placa para quantificar e graduar a intensidade da coloração da placa bacteriana. Para tanto, as superfícies vestibulares dos dentes foram divididas virtualmente em quatro porções horizontais, e graduadas por porcentagem de cobertura de placa bacteriana (Tabela 1). A intensidade da cor da placa recebeu o valor um para a placa clara e dois para a escura. Para calcular o índice de placa bacteriana multiplicou-se o valor da cobertura pela intensidade da cor de cada dente e, posteriormente, os valores foram somados e divididos pelo número de dentes examinados. Os dentes foram o incisivo lateral (I3), o

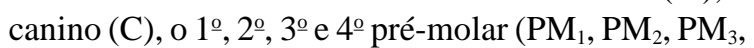
$\mathrm{PM}_{4}$ ) superior direito e o canino (C), o $2^{\circ}, 3^{\circ}$ e $4^{\circ}$ prémolar $\left(\mathrm{PM}_{2}, \mathrm{PM}_{3}, \mathrm{PM}_{4}\right)$ e o $1^{\circ}$ molar $\left(\mathrm{M}_{1}\right)$ inferior esquerdo. Os dados foram anotados em protocolos apresentado na figura 1 .

A técnica de escovação utilizada foi a de Starkey e a de Fones. Uma das mãos do operador afastou os lábios e bochecha, enquanto a outra executou os movimentos de escovação circulares nas faces vestibulares dos dentes superiores e inferiores (PINTO \& ISSÁO, 1988), durante um minuto cronometrado.

Não foi utilizado nenhum tipo de sedativo ou tranqüilizante para os animais, quando necessário algum tipo de contenção, um dos membros da equipe a realizava. A quantidade de placa bacteriana removida em cada método foi comparada usando o teste Z, e o índice de placa antes/após escovação foi comparado usando o teste $t$ de Student, em nível de significância de 5\% (VIEIRA, 1980).

Tabela 1 - Porcentagem de cobertura de placa bacteriana na face vestibular dos dentes em cães.

\begin{tabular}{lc}
\hline CODIFICAÇÃO & QUANTIDADE (\%) \\
\hline 0 & Sem placa \\
1 & $01-24$ \\
2 & $25-49$ \\
3 & $50-74$ \\
4 & $75-100$ \\
\hline
\end{tabular}




\section{RESULTADOS E DISCUSSÃO}

A placa bacteriana é fator primário para a halitose (RICHTER, 1996; CULHAM \& RAWLINGS, 1998), gengivite, cálculo dentário, doença periodontal (SILVA et al., 1997; DUPONT, 1998; GROVE, 1998; HARVEY, 1998), sendo que esta pode causar conseqüências sistêmicas (EISNER, 1989; DEBOWES et al., 1996). Neste experimento, observou-se que a escovação foi capaz de remover a placa bacteriana em $96,95 \%$ quando se utilizou a escova dental e $81,40 \%$, para a dedeira. Observando a tabela 2 , verifica-se que houve diferença significativa antes e após a escovação em ambos os métodos, diminuindo os riscos que a placa bacteriana pode causar.

O índice médio de placa bacteriana nos grupos I e II antes da escovação foram 3,20 e 3,26; e após escovação foi de 0,10 e 0,59 , respectivamente. A determinação do índice de placa de LOGAN \& BOYCE (1994) adotado neste trabalho só foi possível mediante aplicação de solução evidenciadora de placas bacterianas (Violeta de Genciana à $0,1 \%$ ), por permitir a visualização da quantidade e intensidade de cor das placas bacterianas antes e após escovação.

$\mathrm{O}$ método de afastamento dos lábios e bochechas com uma das mãos, adotado neste experimento, permitiu a escovação simultânea das faces vestibulares dos dentes superiores e inferiores dos cães. O sucesso da escovação está relacionado ao condicionamento que o proprietário deve ter com o seu cão desde filhote (DUPONT, 1998). Tal aspecto pode explicar a desnecessária utilização de sedativos ou tranqüilizantes nos animais deste trabalho. $\mathrm{O}$ método de contenção, quando necessário, deve contar com a ajuda de outro membro da família.

A escova ideal para cães deve ter cerdas macias e se adaptar ao formato e tamanho da boca do animal (DUPONT, 1998). Devido à escova infantil e a dedeira usadas para este estudo serem compatíveis com estas recomendações é que foi possível obter os resultados positivos.

Considerando que, no presente estudo não foi observada diferença significativa, na remoção da placa bacteriana, entre os instrumentos avaliados (Tabela 2), a falta de informação dos proprietários de cães em relação à necessidade de uma escovação

Tabela 2 - Índice de placa bacteriana nos grupos I e II antes e depois da escovação e a diferença.

\begin{tabular}{lccc}
\hline Grupo & Antes & Depois & Diferença \\
\hline I - Escova & $3,20^{\mathrm{a}}$ & $0,10^{\mathrm{b}}$ & $3,10^{\mathrm{c}}$ \\
II - Dedeira & $3,26^{\mathrm{a}}$ & $0,59^{\mathrm{b}}$ & $2,67^{\mathrm{c}}$ \\
\hline
\end{tabular}

a/a, b/b e c/c - não houve diferença estatística $\mathrm{a} / \mathrm{b}$ - houve diferença estatística

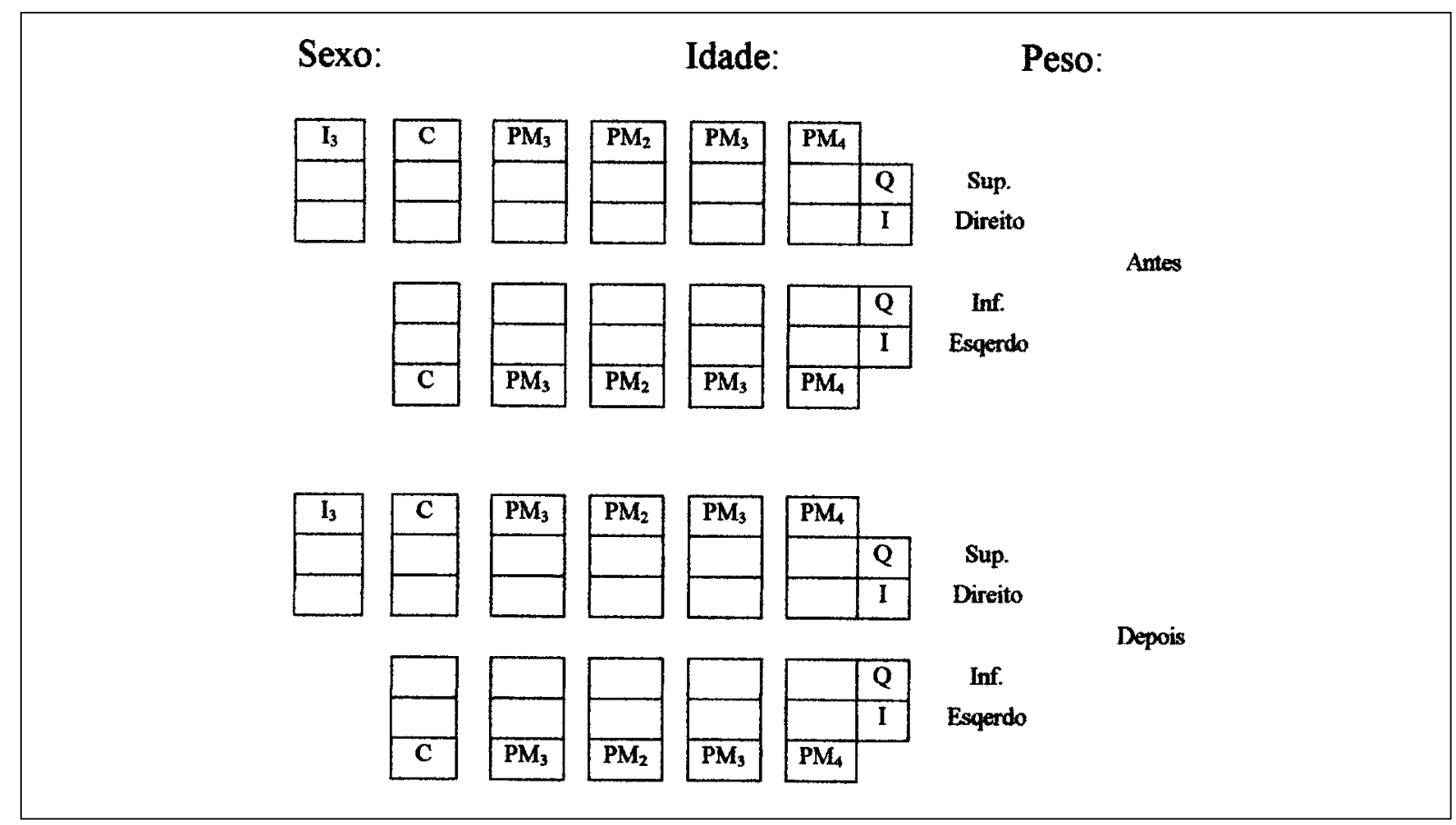

Figura 1 - Protocolo de anotação dos dados para obtenção do índice de placa bacteriana antes e depois da escovação de cada animal 
dental freqüente (TROMP et al., 1986; CORBA et al., 1986; DUPONT, 1998) dificulta a manutenção da saúde bucal dos animais. Como a escovação realizada tanto com escova dental quanto com a dedeira foram eficientes para reduzir a quantidade de placa bacteriana, a orientação aos proprietários sobre a importância da escovação torna-se fundamental.

\section{CONCLUSÕES}

A escova dental e a dedeira são eficientes na remoção da placa bacteriana dental em cães, não ocorrendo diferença significativa entre os dois métodos. A escolha do instrumento manual utilizado na remoção da placa bacteriana em cães, deve considerar a facilidade individual do proprietário em relação ao manuseio destes instrumentos.

\section{FONTES DE AQUISIÇÃO}

a - Dent prev Baby. Lorena/SP.

b - Animalissimo. São Paulo/SP

c - Clorox. Gravataí/RS.

d - Color Plac. São Paulo/SP.

\section{REFERÊNCIAS BIBLIOGRÁFICAS}

ANDRADE JUNIOR, A.C.C. Estudo in vitro da abrasividade de dentifrícios. Rev Odontol Univ São Paulo, v.12, n.3, p.231-236, 1998.

COLMERY, B.; FROST, R. Periodontal etiology and pathogenesis. Vet Clin North Amer: small anim pract, v.16, n.5, p.817-833, 1986.

CORBA, N.H.C.; JANSEN, J.; PILOT, T. Artificial periodontal defects and frequency of tooth brushing in beagle dogs. Clin Periodontol, v.13, n.3, p.186-189, 1986.

CULHAM, N.; RAWLINGS, J.M. Oral malodor and its relevance to periodontal disease in the dog. J Vet Dent, v.15, n.4, p.165-168, 1998.

D’APINO, P.H.P. Monobloco - Avaliação comparativa de uma nova escova dental destinada a programas de saúde coletiva. Caderno ABOPREV, p.45-55, 1990, 1991, 1992.

DUPONT, G.A. Understanding dental plaque; biofilm dynamics. J Vet Dent, v.14, n.3, p.91-93, 1997.
DUPONT, G.A. Prevention of periodontal disease. Vet Clin North Amer: small anim pract, v.28, n.5, p.1129-1145, 1998.

DEBOWES, L.J. et al. Association of periodontal disease and histologic lesions in multiple organs from 45 dogs. J Vet Dent, v.13, n.2, p.57-60, 1996.

EISNER, E. Dental prophylaxis: another piece in the preventive care mosaic. Vet Medicine, v.84, n.11, p.1047, 1989.

EURIDES, D. et al. Placa bacteriana dentária em cães. Ciência Rural, v.26, n.3, p.419-422, 1996.

GROVE, T.K. Treatment of periodontal disease. Vet Clin North Amer: small anim pract, v.28, n.5, p.1147-1164, 1998.

HARVEY, C.E. Periodontal disease in dogs: etiopathogenesis, prevalence, and signicance. Vet Clin North Amer: small anim pract, v.28, n.5, p.1111-1227, 1998.

JENSEN, L. et al. Resuction in accumulation of plaque, stain, and calculus in dogs by dietary means. J Vet Dent, v.12, n.4, p.161-163, 1995.

JONGENELIS, A.P.J.M.; WIEDEMANN, W. A comparison of plaque removal effectiveness of electric versus a manual toothbrush in children. J Dent Child, p.176- 182, 1997.

LOGAN, E.I.; BOYCE, E.N. Oral health assessment in dogs: parameters and methods. J Vet Dent, v.11, n.2, p.58-63, 1994.

LYON, K.F. Dental home care. J Vet Dent, v.8, n.2, p.2630, 1991.

MILLER, B.R.; HARVEY, C.E. Compliance with oral hygiene recommendations following periodontal treatment in clientowned dogs. J Vet Dent, v.11, n.1, p.18-19, 1994.

PINTO, A.C.G.; ISSÁO, M. Manual de odontopediatria. 7.ed. São Paulo : Artes médicas, 1988. 263p.

RICHTER, J.L. Diagnosis and treatment of halitosis. Compend Contin Educ Dent, v.17, p.370-384, 1996.

SILVA, S.C. et al. Prevenção periodontal: controle mecânico de placa. Rev Periodontia, v.6, p.211-215, suplemento 1997.

TROMP, J.A.H.; RIJN, L.J.; JANSEN, J. Experimental gingivitis and frequency of tooth brushing in the beagle dog model. Clin Periodontol, v.13, n.3, p.190-194, 1986.

VIEIRA, S. Introdução à estatística. 3.ed. Rio de Janeiro: Campus, 1980. 196p. 